\title{
Epiphytic and Endophytic Bacteria on Olive Tree Phyllosphere: Exploring Tissue and Cultivar Effect
}

\author{
Diogo Mina ${ }^{1} \cdot$ José Alberto Pereira ${ }^{1} \cdot$ Teresa Lino-Neto $^{2} \cdot$ Paula Baptista $^{1}$ (i)
}

Received: 7 October 2019 / Accepted: 9 January 2020

(C) Springer Science+Business Media, LLC, part of Springer Nature 2020

\begin{abstract}
Variation on bacterial communities living in the phyllosphere as epiphytes and endophytes has been attributed to plant host effects. However, there is contradictory or inconclusive evidence regarding the effect of plant genetics (below the species' level) and of plant tissue type on phyllosphere bacterial community assembly, in particular when epiphytes and endophytes are considered simultaneously. Here, both surface and internal bacterial communities of two olive (Olea europaea) cultivars were evaluated in twigs and leaves by molecular identification of cultivable isolates, with an attempt to answer these questions. Overall, Proteobacteria, Actinobacteria and Firmicutes were the dominant phyla, being epiphytes more diverse and abundant than endophytes. Host genotype (at cultivar level) had a structuring effect on the composition of bacterial communities and, in a similar way, for both epiphytes and endophytes. Plant organ (leaf vs. twig) control of the bacterial communities was less evident when compared with plant genotype and with a greater influence on epiphytic than on endophytic community structure. Each olive genotype/plant organ was apparently selective towards specific bacterial operational taxonomic units (OTUs), which may lead to specific feedbacks on fitness of plant genotypes. Bacterial recruitment was observed to happen mainly within epiphytes than in endophytes and in leaves as compared with twigs. Such host specificity suggested that the benefits derived from the plantbacteria interaction should be considered at genetic levels below the species.
\end{abstract}

Keywords Olea europaea L. $\cdot$ Microbiota $\cdot$ Diversity $\cdot$ Organ specificity $\cdot$ Host specificity

\section{Introduction}

The phyllosphere (a sensu lato term applied for describing the aerial parts of plants) has been recognized to be an important habitat for a myriad of microorganisms [1]. One of the major groups of microorganisms inhabiting this habitat, either in terms of diversity or abundance, is bacteria $[2,3]$. They may live on the surface (generally referred as epiphytes) and/or inside (endophytes) the plant tissues [4], setting up complex

Electronic supplementary material The online version of this article (https://doi.org/10.1007/s00248-020-01488-8) contains supplementary material, which is available to authorized users.

Paula Baptista

pbaptista@ipb.pt

1 Centro de Investigação de Montanha (CIMO), Instituto Politécnico de Bragança, Campus de Santa Apolónia,

5300-253 Braganca, Portugal

2 Biosystems and Integrative Sciences Institute (BioISI), Plant Functional Biology Center (CBFP), University of Minho, Campus de Gualtar, 4710-057 Braga, Portugal microbial interactions with great impact for plant growth and productivity $[5,6]$.

Previous studies have demonstrated that different environmental and plant-dependent factors, such as host species and plant organ, contribute to the shaping of bacterial communities in the phyllosphere [7-9]. Most of these studies have focused on those bacteria associated to the phyllosphere of specific host species [10-12]. The variation in bacterial community composition among different genotypes from the same species has been generally overlooked. Although rare, such studies have been often limited to temperate forests $[12,13]$ or horticultural species $[14,15]$, often with contradicting results. For instance, Hunter et al. [14] detected differences in leaf bacterial community composition among lettuce varieties, whereas Rastogi et al. [15] did not find such differences. In addition, most of these previous studies have focused exclusively in epiphytes [10-13, 15]. Studies focusing on both epiphytic and endophytic communities are scarcer and provided limited insights into the forces shaping both bacterial communities in the phyllosphere $[8,14]$. The epiphytic community is faced with a poor nutrient and variable environment, characterized by the permanent changes of 
temperature, humidity and radiation [1]. The endophytic community, on the other hand, resides within a more stable environment compared with epiphytes, being the defense response of host plant the main challenge that they would probably need to face [16]. There are few comparisons of epiphytic and endophytic phyllosphere bacterial communities, especially comparisons using the same plant material. Such studies performed either on Arabidopsis thaliana [8] or lettuce [14] leaves indicated that bacterial epiphytes were more diverse and abundant than endophytes. If both bacterial communities inhabiting the phyllosphere are shaped by the same or different factors, or if the importance of shaping factors changes according to the plant organ remains to be elucidated.

Here, we characterize and compare the assembling of bacterial epiphytes and endophytes associated to leaves and twigs of two olive tree cultivars. Olive (Olea europaea L.) is a typical tree of the Mediterranean Basin [17], where around 95\% of the world olive crop area is located [18]. Mediterraneanclimate, characterized by severe water deficits in summer and abundant water in winter when temperatures and light are low [19], can be an extreme habitat for phyllospheric microorganisms. The natural characteristics of these Mediterraneanclimate ecosystems make them highly interesting for studying phyllosphere microbial adaptations [20]. Climate change scenarios foresee temperatures increases in many Mediterranean regions [21], revealing the importance of such studies. Most research on olive tree phyllosphere microbiota has mainly focused on fungal communities, either exclusively on endophytic [22-25] or both endophytic and epiphytic populations [26]. As far as we know, there are only one study focusing on archaeal and bacterial diversity in olive tree phyllosphere [27]. Using olive tree growing in Mediterranean-climate ecosystem, the present work seeks to answer the following questions: (i) How do bacterial communities differ in diversity and composition between two host genotypes (at cultivar level) and two plant organs (leaves and twigs)? (ii) Does host genotype (at cultivar level) and plant organ affect the assembling of endophytic and epiphytic bacterial communities in a similar way? (iii) Can we determine indicator communities associated with cultivar and plant organ? The bacterial communities structure in olive tree phyllosphere was determined using a culture-dependent approach (followed by the identification of rRNA 16S barcodes) foreseeing a possible application of those microbiota on future interaction studies.

\section{Materials and Methods}

\section{Study Site and Sample Collection}

Sampling was performed from September to October 2015, in three olive orchards located in Mirandela, Portugal, at coordi-

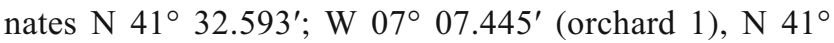

32.756'; W $07^{\circ} 07.590^{\prime}$ (orchard 2) and N 41 $29.454^{\prime} ; \mathrm{W}$ $07^{\circ} 30.398^{\prime}$ (orchard 3). In the selected orchards, trees were planted with $7 \times 7 \mathrm{~m}$ spacing and were managed following integrated production guidelines [28]. In each orchard, 7 olive trees of cv. Cobrançosa and 7 olive trees of cv. Verdeal Transmontana were randomly selected, resulting in the evaluation of 21 olive trees from each cultivar. Apparently, healthy branches of each tree were randomly collected with sterilized shears and gloves, placed into sterile roll bags and brought to the lab on ice. Plant material was stored at $4{ }^{\circ} \mathrm{C}$ up to processing that occurred within the next $24 \mathrm{~h}$ (for epiphytes) or $72 \mathrm{~h}$ (for endophytes).

\section{Bacterial Isolation}

From two different branches of each tree, around $1 \mathrm{~g}$ of leaves and twigs were detached and used to isolate epiphytes and endophytes. Leaves and twigs were separately immersed in $10 \mathrm{~mL}$ of peptone water $(10 \mathrm{~g} / \mathrm{L}$ peptone, $5 \mathrm{~g} / \mathrm{L}$ sodium chloride) and shaken gently on a rotary shaker $(100 \mathrm{rpm})$, for one hour, at room temperature. Aliquots of $100 \mu \mathrm{L}$ of the microbial suspension were plated in triplicate onto Luria Bertani (LB) agar medium $(10 \mathrm{~g} / \mathrm{L}$ peptone, $5 \mathrm{~g} / \mathrm{L}$ yeast extract, $5 \mathrm{~g} /$ $\mathrm{L}$ sodium chloride and $10 \mathrm{~g} / \mathrm{L}$ agar) and incubated at $25^{\circ} \mathrm{C}$ in the dark until bacterial growth. Daily observations were performed in order to isolate and count bacterial colonies. The number of colonies (CFU; Colony Forming Units) present on $1 \mathrm{~cm}^{2}$ surface area of leaves/twigs was transformed to $\log$ CFU per $\mathrm{cm}^{2}$. To estimate leaf and twig surface areas, the ellipse $(A=\pi a b x 2)$ and cylinder $\left(A=2 \pi r h+2 \pi r^{2}\right)$ equations were respectively used, where $A$ is the area, $a$ and $b$ are the corresponding longitudinal and transverse axes of the leaf and $\mathrm{r}$ and $\mathrm{h}$ are the radius and height of the twig segments. The obtained average area for leaves was $39.5 \pm 11.4 \mathrm{~cm}^{2}$ for cv. Cobrançosa and $37.7 \pm 13.0$ for cv. Verdeal Transmontana and for twigs was $11.0 \pm 3.6 \mathrm{~cm}^{2}$ for cv. Cobrançosa and $11.0 \pm 2.3$ for $\mathrm{cv}$. Verdeal Transmontana.

From the same plant material used to isolate epiphytes, five segments of twigs and five leaves from each branch were randomly selected and used to isolate endophytic bacteria. For this, leaves and twigs were first surface-disinfected through sequential immersion in $70 \%(\mathrm{v} / \mathrm{v})$ ethanol for $1 \mathrm{~min}$ and $3 \%(\mathrm{v} / \mathrm{v})$ sodium hypochlorite for $1 \mathrm{~min}$ and then rinsed three times (1 min each) with sterile distilled water. To ensure the efficiency of the sterilization protocol, the surface of each leaf and twig were imprinted onto LB agar medium. Each fragment was cut into five pieces (ca. $5 \times 5 \mathrm{~mm}$ ), which were then transferred to LB agar medium for allowing endophytes growth. Altogether, in this work, a total of 4200 plant segments were used for evaluating endophytic communities, resulting from replicates in the following experimental design: 3 orchards $\times 2$ olive tree cultivars $\times 7$ trees $\times 2$ plant organs $\times 2$ branches per tree $\times 5$ leaves or twigs $\times 5$ plant segments. 
Plates were incubated at $25^{\circ} \mathrm{C}$ in the dark. Daily observations were performed in order to count and isolate the bacterial colonies growing out from the plant tissues segments.

\section{Bacterial Identification}

Bacterial isolates were first grouped by colony morphology (color, form, elevation and edges). Two representatives of each morphotype were selected for molecular identification using V1-V4 regions from 16S rRNA. Genomic DNA was extracted and purified using REDExtract-N-Amp ${ }^{\mathrm{TM}}$ Plant $P C R$ kit (Sigma, Poole, UK) following manufacturer instructions. The extracted genomic DNA was used as template for V1-V4 region amplification, using the forward V1F (5'AGAGTTTGATCCTGGCTCAG-3') and reverse V4R (5'TACNVGGGTATCTAATCC-3') primers for $16 \mathrm{~S}$ amplicon region [29]. Amplifications occurred in a MyCycler ${ }^{\mathrm{TM}}$ Thermocycler (Bio-Rad) thermocycler, using $50 \mu \mathrm{L}$ PCR reactions, which contained $7 \mu \mathrm{L}$ of $10 \mathrm{x}$ buffer, $2.5 \mu \mathrm{L}$ of $25 \mathrm{mM}$ $\mathrm{MgCl}_{2}, 1 \mu \mathrm{L}$ dNTPs of $10 \mathrm{mM}, 1 \mu \mathrm{L}$ of each primer $(10 \mu \mathrm{M})$, $3 \mu \mathrm{L}$ of DNA extract and $0.25 \mu \mathrm{L}$ of DFS-Taq DNA Polymerase $(5 \mathrm{U} / \mu \mathrm{L})(\mathrm{BIORON} \mathrm{GmbH})$. Cycling conditions were $94^{\circ} \mathrm{C}$ for $5 \mathrm{~min}$, followed by 35 cycles of $94^{\circ} \mathrm{C}$ for $50 \mathrm{~s}$, $45{ }^{\circ} \mathrm{C}$ for $30 \mathrm{~s}$ and $72{ }^{\circ} \mathrm{C}$ for $90 \mathrm{~s}$, with a final extension of $72{ }^{\circ} \mathrm{C}$ for $5 \mathrm{~min}$. The amplified products were purified and sequenced at Macrogen Inc. (Madrid). Taxonomic identification was performed by using the NCBI database (http://www. ncbi.nlm.nih.gov) and BLAST analysis sorted by higher identity score and lowest E-value. For sequence identities > 98\%, the genus and species were accepted; for sequence identities between $95 \%$ and $97 \%$, only the genus was accepted; and for sequence identities $<95 \%$, isolates were labeled as 'unknown' bacteria [30]. Pure cultures of each identified isolate were deposited and are preserved in the culture collection of the Mountain Research Centre (CIMO), Instituto Politécnico de Bragança (Portugal).

\section{Diversity and Community Analysis}

Epiphytic and endophytic bacterial diversity in each olive tree phyllosphere was assessed by evaluating the abundance (i.e., relative number of isolates), richness (i.e., number of operational taxonomic units-OTUs) and diversity by computing Simpson's Reciprocal Index (1/D) in Species Diversity and Richness v. 4.0 [31]. Diversity values of the entire, epiphytic and endophytic bacterial communities associated to cvs. Cobrançosa and Verdeal Transmontana are presented as the mean of replicates (i.e., tree), displaying respective SE values. Means were compared by using an analysis of variance (ANOVA) with SPSS v. 22, and the significant differences among means were determined by Tukey's test $(p<0.05)$.

Non-metric multidimensional scaling (NMDS) was carried out to determine the similarity in bacterial community composition among host cultivars (i.e., Cobrançosa and Verdeal Transmontana) and plant organ (i.e., leaves and twigs). This analysis was performed for the entire, epiphytic and endophytic bacterial communities, by using two similarity indexes. Jaccard's similarity index compares samples based on presence/ absence differences [32], while Bray-Curtis coefficient takes into account not only the presence/absence of bacterial species but also their abundance [33]. NMDS calculates a stress value (Kruskal's stress), which assesses how well the derived ordination fits the given dissimilarities. According to Clarke [33], Kruskal's stress values less than 0.2 represent plots with good ordination. Analysis of similarity (ANOSIM) was used to determine if differences in bacterial composition among samples are statistically significant. This analysis was performed from BrayCurtis distance matrices (obtained from raw abundance data) with 999 permutations. ANOSIM generates an $R$-value ranging from 0 (completely similar) to 1 (completely dissimilar) and a $p$ value (significant level below 0.05) [34]. Both NMDS and ANOSIM analyses were performed by using the Community Analysis Package v. 4.0 [35]. The relative abundance of bacterial families that exhibited a significant $(p<0.05)$ differential abundance across host cultivar and/or plant organ were represented in a heatmap using the heatmap. 2 function in the gplots package of $R$ software [36].

Indicator Value (IndVal) analysis [37] was used to identify bacterial OTUs that are characteristic (habitat specialists) of each host cultivar and plant organ. This method identifies indicator species based on their specificity (i.e., uniqueness) to a particular habitat (A) and their frequency in that habitat (B). The IndVal values were computed by $R$ software, using the function multipatt from indicspecies package. Only bacterial genera with significant $(p<0.05)$ IndVal values $>0.3$ were considered, as this latter value can be regarded as a good threshold for habitat specialization [37].

\section{Factors Driving Bacterial Communities in Olive Tree Phyllosphere}

A co-inertia analysis (CIA) coupled with Monte Carlo permutation tests was used to determine whether epiphytic and endophytic bacterial communities were similarly affected by host cultivar and plant organ. This analysis establishes a costructure between sets of variables (host cultivar and plant organ) that are linked by the same bacterial genera [38]. For performing this analysis, the bacterial abundance (at genus level) was used for the dudi.pca and coinertia functions in the ade4 package [39] of $R$ software [36]. Using the same package, the table.value function was used to visualize the results in a factorial map. To assess the significance of CIA results, Monte Carlo permutation tests were used for obtaining a $R V$-coefficient. This coefficient, which varies between 0 and 1 , gives an indication of the correlation between two data tables: the closer the coefficient to 1 , the stronger the 
correlation between tables [40]. To estimate the proportion of bacterial community variation explained by host cultivar and plant organ, variation partitioning analysis was performed with vegan package using varpart function, in $R$ software. The significance of each fraction was tested using the anova function, applied on the object resulting from a previous canonical correspondence analysis (CCA) using the $c c a$ function. These analyses were performed for the entire, epiphytic and endophytic bacterial communities.

\section{Results}

\section{Composition and Diversity of Epiphytic and Endophytic Bacterial Communities}

A total of 421 bacterial isolates belonging to 89 bacterial operational taxonomic units (OTUs) were recovered from both leaves and twigs of olive trees from cvs. Cobrançosa and Verdeal Transmontana (Fig. S1). A larger consortium of epiphytic bacteria (65 OTUs, 30 genera, 17 families, 10 orders, 7 classes and 4 phyla) was found when compared with endophytic bacteria (45 OTUs, 16 genera, 12 families, 9 orders, 5 classes and 3 phyla) (Fig. S2). On average, the number of epiphytic OTUs per tree was 1.3 -fold significantly higher $(p<0.001)$ than the number of endophytes (Table S1). Only 21 OTUs were shared by both bacterial communities, representing $24.1 \%$ of the total number of identified OTUs (Fig. S2).

Across all samples, four distinct prokaryotic phyla were detected (Proteobacteria, Actinobacteria, Firmicutes and Bacteroidetes), although more than $83 \%$ of total OTUs belonged to Proteobacteria and Actinobacteria phyla (Fig. S1). Epiphytic bacterial community was mostly composed by members belonging to Proteobacteria phylum (60.8\% of the total epiphytic bacteria strains), mainly from Gammaproteobacteria class (55.7\%), in which the most abundant order was Pseudomonadales (38.2\%) (Fig. S2a). The second most abundant phylum was Actinobacteria (22.7\%) and only included Actinomycetales members, which was then followed by Firmicutes (14.3\%). The most abundant endophytic bacteria also belonged to the Proteobacteria phylum (71.6\% of the total identified endophytes), $74.5 \%$ of which were from Gammaproteobacteria class, mostly including members of Pseudomonadales and Enterobacteriales orders (64.6 and $34.7 \%$ of the corresponding class) (Fig. S2b). Other taxa were represented by less than $26 \%$.

\section{Bacterial Diversity Differs among Host Cultivars and Plant Organs}

The bacterial abundance (relative number of isolates), richness (number OTUs/tree) and alpha diversity (Simpson's index) differed significantly among olive tree cultivars, but these differences were greater for endophytes when compared with epiphytes (Fig. 1; Table S1). For epiphytic community, the identified bacterial abundance and alpha diversity on cv. Verdeal Transmontana were 1.5 -fold and 1.2-fold higher $(p<0.01)$, respectively, when compared with cv. Cobrançosa. These differences were higher for endophytes, which also presented in cv. Verdeal Transmontana a higher abundance (up to 2.2-fold, $p<0.01$ ) and alpha diversity (up to 2.4 -fold, $p<0.001$ ), also exhibiting a significantly higher richness (up to 2.8-fold, $p<0.001$ ) when compared with cv. Cobrançosa.

Leaves and twigs exhibited different bacterial abundances, displaying twigs a higher abundance (up to 1.7-fold, $p<0.001$ ) when compared with leaves (Fig. 2; Table S1). This increase was mostly due to an increase on the abundance of epiphytic community (up to 1.8 -fold, $p<0.001$ ) since the endophytic bacterial community almost remained unchanged in both organs. In contrast, a significant reduction (1.2-fold, $p<0.001$ ) on the number of isolated epiphytic OTUs/tree was detected on twigs compared with leaves, revealing a higher representation of each OTU in twigs. In any case, no significant differences were detected for alpha diversity in both organs. The endophytic bacterial abundance, richness and diversity were not significant between leaves and twigs.

The entire bacterial communities present on leaves and twigs of cvs. Cobrançosa and Verdeal Transmontana were significantly distinct, as indicated by non-metric multidimensional scaling (NMDS) plots (Fig. 3), taking into account different similarity measures of bacterial communities (BrayCurtis coefficient and Jaccard's similarity indexes). A clearer separation of bacterial communities was noticeable when the ordination was based on the Jaccard's similarity index (Kruskal stress $=0.14$ ), which only considers the presence/ absence of bacterial OTUs disregarding their abundance [32]. This was also the case of epiphytic communities (Kruskal stress $=0.13$ ), but not with the endophytic community that was better discriminated when using the Bray-Curtis coefficient (Kruskal stress $=0.14$ ) that also considers the abundance of each bacterial OTU. This reveals that the abundance of endophytes is an important factor to take into consideration for endophytic communities. Moreover, while bacterial epiphytes were clearly separated considering olive cultivar and organ, this separation was not so well observed on bacterial endophytes.

The analysis of similarities (ANOSIM) using Bray-Curtis coefficients also revealed distinct bacterial communities from cv. Cobrançosa and cv. Verdeal Transmontana $(R=0.312$, $p=0.001$; Table S2). However, differences between cultivars were greater within endophytes $(R=0.390, p=0.001)$ than within epiphytes $(R=0.207, p=0.001)$ and greater in leaves ( $R=0.591, p=0.001)$ than in twigs $(R=0.469, p=0.001)$. The endophytic community colonizing leaves displayed the greatest differentiation among both cultivars $(R=0.624, p=$ 


\section{Abundance}

Epiphytes
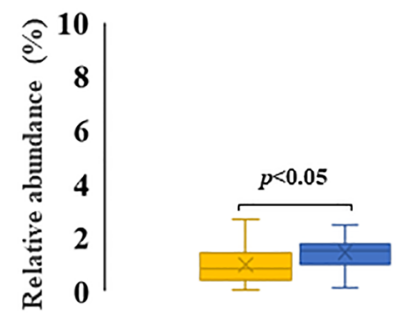

Endophytes
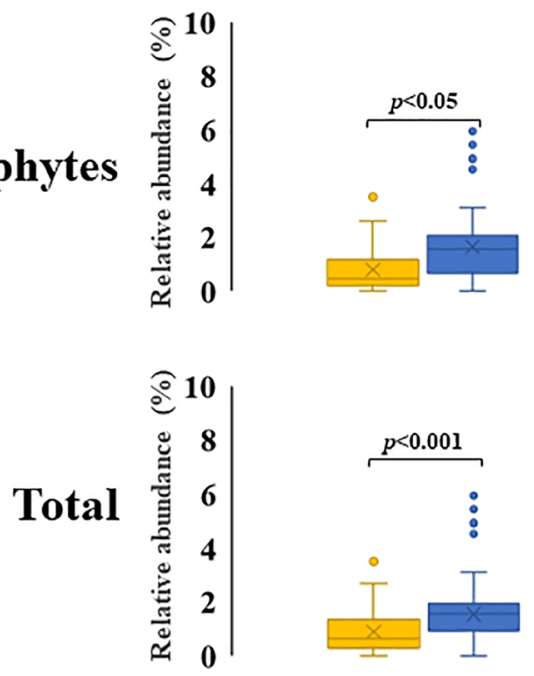

\section{OTUs/tree}
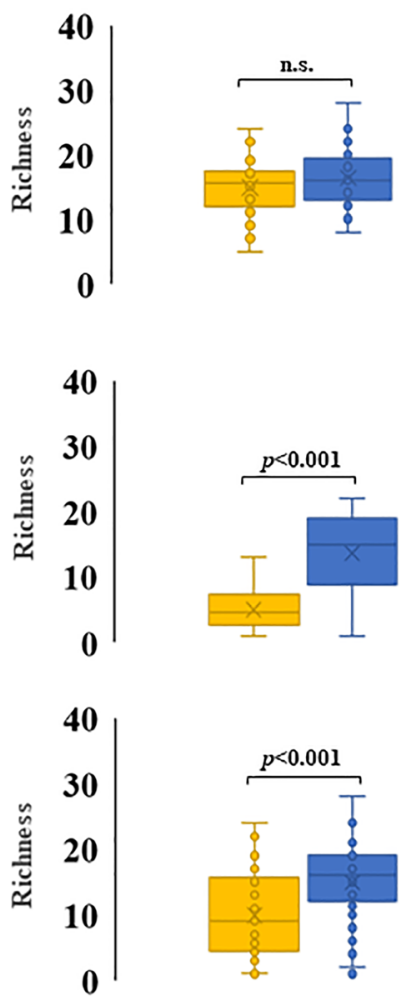

Alpha diversity
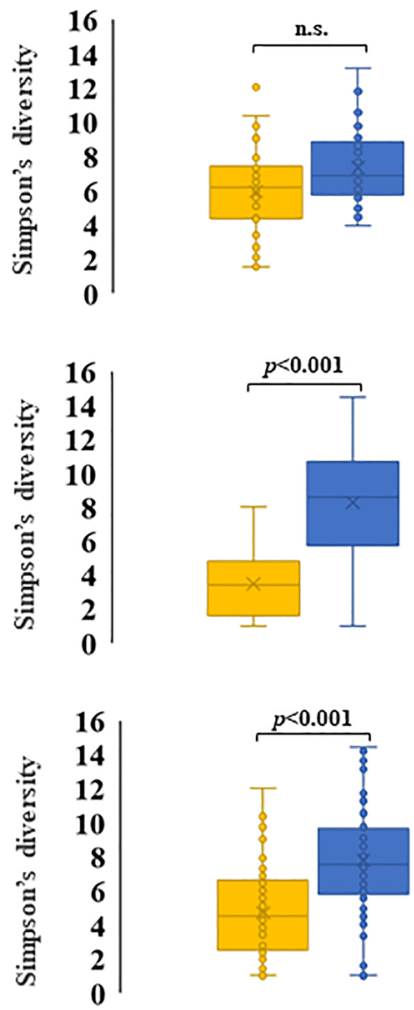

cv. Cobrançosa

cv. Verdeal-Transmontana

Fig. 1 Comparison of epiphytic, endophytic and whole bacterial communities between Cobrançosa and Verdeal Transmontana cultivars regarding their abundance (relative abundance per tree), richness (number of OTUs/tree) and alpha diversity (Simpson's index). Box plots depict medians (central horizontal lines), the inter-quartile ranges (boxes), 95\% confidence intervals (whiskers) and outliers (dots). Significant differences between pairs of values are showed over horizontal lines. (n.s. not significant)
0.001). These differences could be due to the enrichment of cv. Cobrançosa on bacteria belonging to Caulobacteriaceae and Xanthomonadaceae families, while cv. Verdeal Transmontana was mostly inhabited by bacteria from Staphylococcaceae, Alcaligenaceae and Paenibacillaceae families (Fig. 4a).

The composition of bacterial communities on leaves was distinct from those on twigs $(\mathrm{R}=0.252, p=0.001$; Table S2) but was more dissimilar for cv. Verdeal Transmontana $(R=$ 0.708, $p=0.001)$ than for cv. Cobrançosa $(R=0.357, p=$ $0.001)$. While cv. Verdeal Transmontana leaves/twigs dissimilarities were greatest within epiphytes $(R=0.787, p=$ $0.001)$, in cv. Cobrançosa, the dissimilarities were greatest within endophytes $(R=0.386, p=0.001)$. Such differences could mainly be due to the enrichment of twigs on bacteria belonging to Paenibacillaceae and depletion on Alcaligenaceae, Corynebacterineae and Staphylococcaceae, when compared with leaves. Depending on its epiphytic or endophytic plant habitat, Microbacteriaceae and Caulobacteriaceae bacterial abundance also contributed to leaves/twigs dissimilarities (Fig. 4b).

\section{Bacterial Composition Is Primarily Shaped by Host Cultivar and Then by Plant Organ}

For testing the relationships between bacterial communities and host cultivars or plant organs, in order to assess whether epiphytic and endophytic bacterial communities were similarly influenced by both variables, a co-inertia analysis was performed. The plant habitat (i.e., internal and external plant tissues) revealed to influence the structure of the entire bacterial community $(R V=0.901 ; p=$ 0.002 ), explaining $5.0 \%$ of the variation in their composition (Table S3). The results also showed that epiphytic and endophytic bacterial communities were similarly affected by host cultivar $(R V=0.847, p=0.002$ and $R V=$ $0.966, p=0.003$, respectively) but differently influenced by plant organ. Indeed, higher significant co-inertia coefficients were found for epiphytic $(R V=0.931, p=0.003)$ when compared with endophytic $(R V=0.739, \mathrm{p}=0.003)$ bacterial communities regarding plant organs. The proportion of variation in bacterial communities that could be 
Abundance

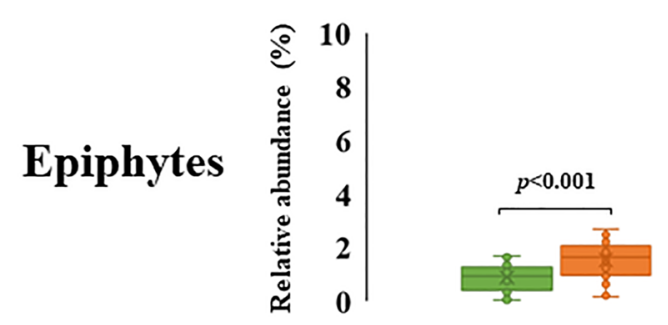

Endophytes
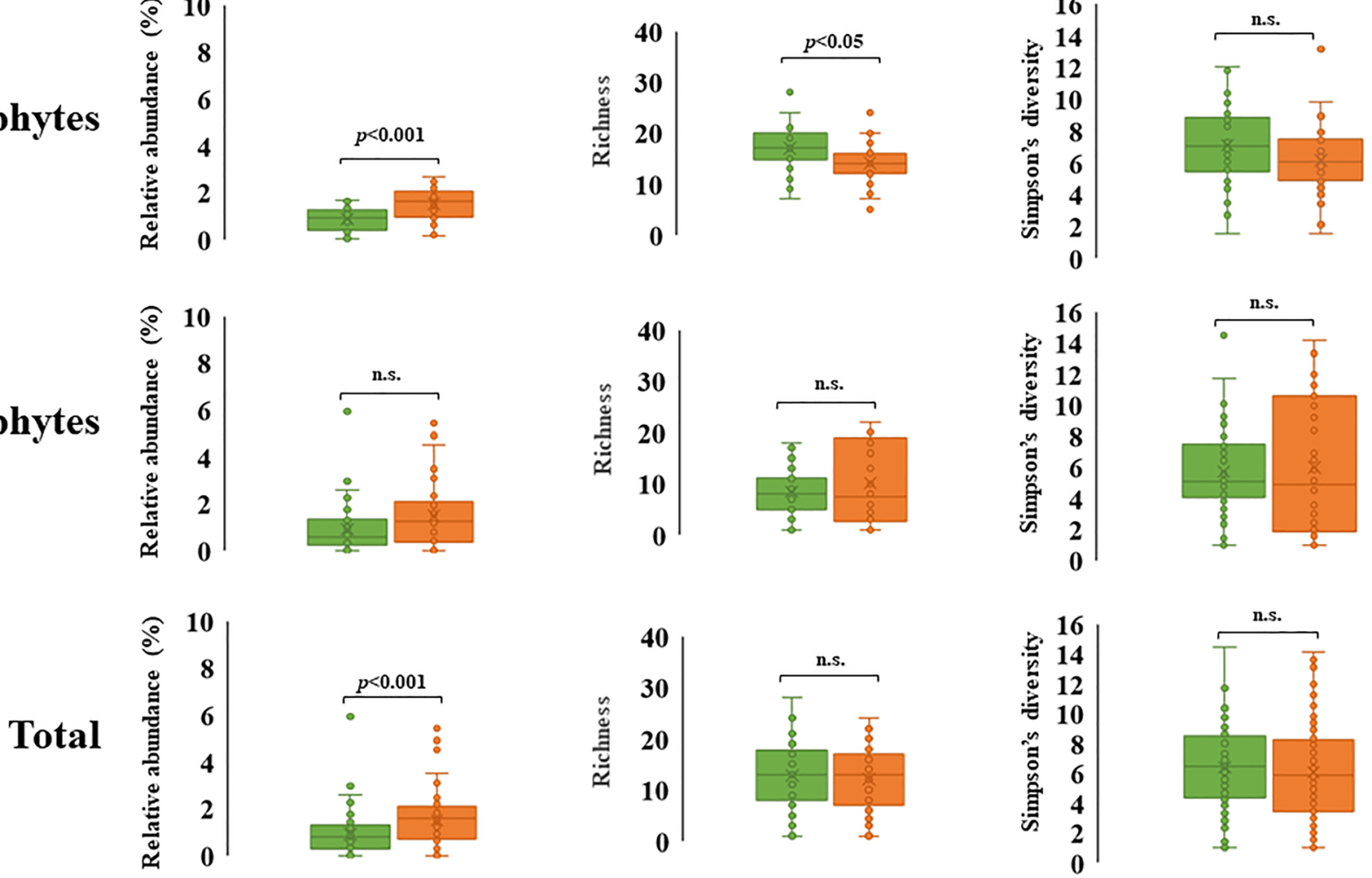

Alpha diversity
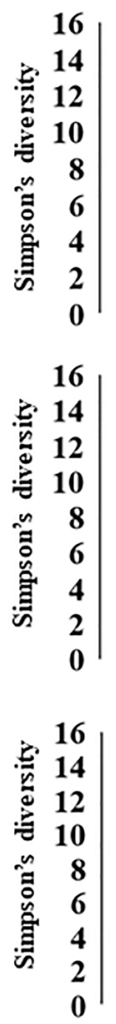

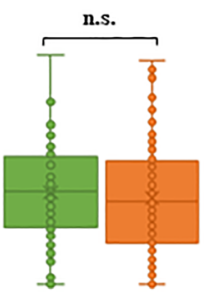

\section{Leaves}

Twigs

Fig. 2 Comparison of epiphytic, endophytic and whole bacterial communities in leaves and twigs regarding their abundance (relative abundance per tree), richness (number of OTUs/tree) and alpha diversity (Simpson's index). Box plots depict medians (central

horizontal lines), the inter-quartile ranges (boxes), 95\% confidence intervals (whiskers) and outliers (dots). Significant differences between pairs of values are showed over horizontal lines. (n.s. not significant)

explained by host cultivar or plant organ factors, as evaluated by a variation partitioning analysis, corroborated these results. While host cultivar accounted for an almost similar variation on epiphytic $(7.7 \%, p=0.005)$ and endophytic $(8.0 \%, p=0.005)$ bacterial communities, the plant organ only explained $2.2 \%(p=0.005)$ of the endophytic bacterial composition variation in contrast with $6.3 \%(p=0.005)$ of epiphytic variation (Table S3). Coinertia analysis also revealed that the bacterial genera that contributed most to bacterial communities distinction in different plant organs were Staphylococcus (within epiphytes) and Ochrobactrum (within endophytes), which were linked with leaves (Fig. 5). Curtobacterium (within epiphytes) and Brevundimonas (within endophytes) were positively correlated with twigs. Host plant cultivars were mostly differentiated by epiphytes belonging to Frondihabitans and Xanthomonas genera, which were related with cv. Cobrançosa and cv. Verdeal Transmontana, respectively.

\section{Habitat Specialists Are Present in Phyllosphere-Associated Bacterial Communities}

An indicator species analysis was carried out in order to identify the characteristic bacterial OTUs from a specific habitat type (i.e., host cultivar and plant organ). In total, 42 bacterial OTUs (out of 89 OTUs, $47.2 \%$ ) displayed significant (IndVal $>0.3, p<0.05$ ) habitat preference, being 23 epiphytes and 19 endophytes (Table S4). Most of these indicator species were present in leaves [cv. Cobrançosa (12) and cv. Verdeal Transmontana leaves (17)], contrasting with those present in twigs [cv. Cobrançosa (4) and cv. Verdeal Transmontana leaves (9)]. The best indicator bacterial OTUs of cv. Cobrançosa (IndVal > 0.7) were the epiphytes Bacillus megaterium, Bacillus subtilis, Curtobacterium oceanosedimentum and Pantoea vagans and the endophytes Pseudomonas aeruginosa, Pseudomonas graminis and Brevundimonas sp. Concerning the cv. Verdeal Transmontana, the best indicator species were the epiphytes Pseudomonas poae, Bacillus cereus, Erwinia olea, Erwinia aphidicola, 
Epiphytics
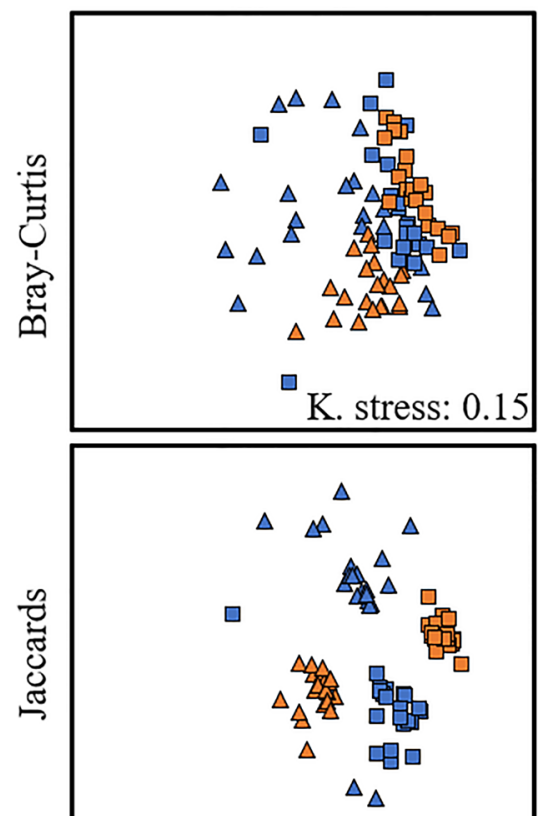

K. stress: 0.13
Endophytics
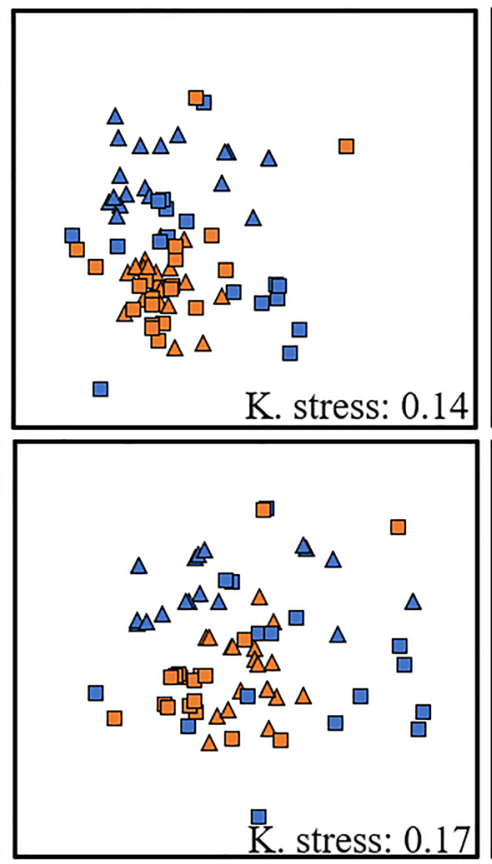

Total

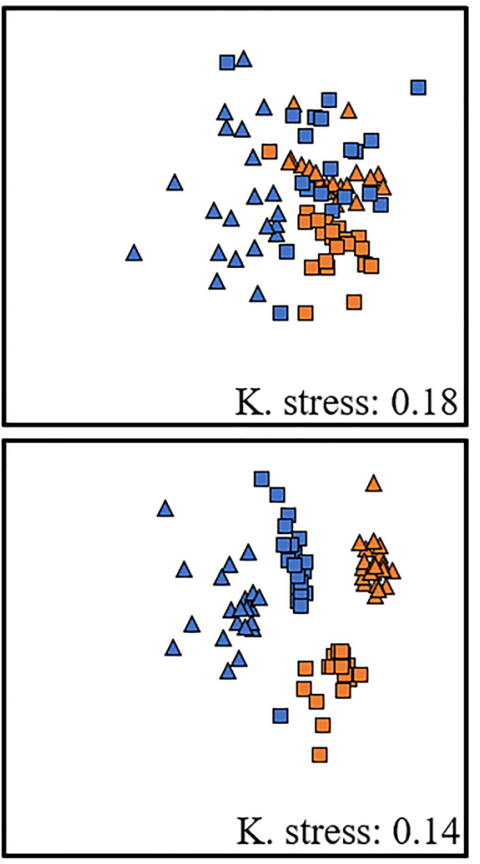

\section{$\Delta$ cv. Cobrançosa leaves \\ cv. Cobrançosa twigs}

Fig. 3 Non-metric multidimensional scale (NMDS) plots corresponding to the clustering of epiphytic, endophytic and whole bacterial communities. Cluster analysis was performed with two different community similarity measures, namely, Bray-Curtis coefficient (raw

Curtobacterium herbarum, Pseudomonas lutea and Pseudomonas septica and the endophytes Pantoea vagans, Pantoea brenneri and seven Pseudomonas OTUs.

\section{Discussion}

Olive trees are highly adapted to low water availability and increased temperature conditions [41]. Their survival ability could be partially related with a significant reservoir of beneficial microorganisms on their phyllosphere. Our results based on culture-dependent method revealed that olive trees growing in the Mediterranean region, where drought conditions are usual and are even becoming more prevalent, are colonized on the phyllosphere by bacterial members belonging to four phyla. Proteobacteria (in particular Gammaproteobacteria class), followed by Actinobacteria and Firmicutes, were the most diverse and abundant phyla, while the presence of bacteria belonging to Bacteriodetes phylum was scarce. Although culture-dependent diversity survey presented lower coverage than culture-independent methods [42], our findings with regard to the most dominant phyla are consistent with those of earlier studies of phyllosphere in the Mediterranean region.

\section{$\triangle \mathrm{cv}$. Verdeal leaves \\ cv. Verdeal twigs}

abundance data) and Jaccard's index (binary data). Bacterial communities from different olive tree cultivar (Cobrançosa or VerdealTransmontana) and plant organ (leaves or twigs) are represented by different colors/shapes

For example, Müller et al. [27] have similarly found a high abundance of members belonging to Proteobacteria, Actinobacteria and Firmicutes phyla in the endosphere of olive leaves collected from different Mediterranean locations. When analyzing the epiphytic leaf community of chestnuts [43] and other perennial species [45] of the Mediterranean region, a predominance of Proteobacteria, Actinobacteria and Firmicutes was similarly observed. All these studies have focused on endophytes, ignoring the epiphytes, or vice-versa.

Members of detected phyla, in particular of Actinobacteria and Firmicutes, often prevail in arid environments [46-48] due to their ability to resist to UV-radiation and desiccation [49]. Their resistance has been mostly attributed to their ability to produce photoprotective pigments [50] and to repair UVdamages through multiple mechanisms [51]. In addition, their ability to produce spores allows their survival in harsh environmental conditions [52]. Hence, these features displayed by bacteria inhabiting the olive tree phyllosphere are likely to increase their resilience and to help the host plant to cope with abiotic stresses associated to Mediterranean climate. Indeed, the microorganisms are thought to have an influential role in governing key bioprocesses under extreme conditions [46]. For example, the phyllospheric bacteria have already been 

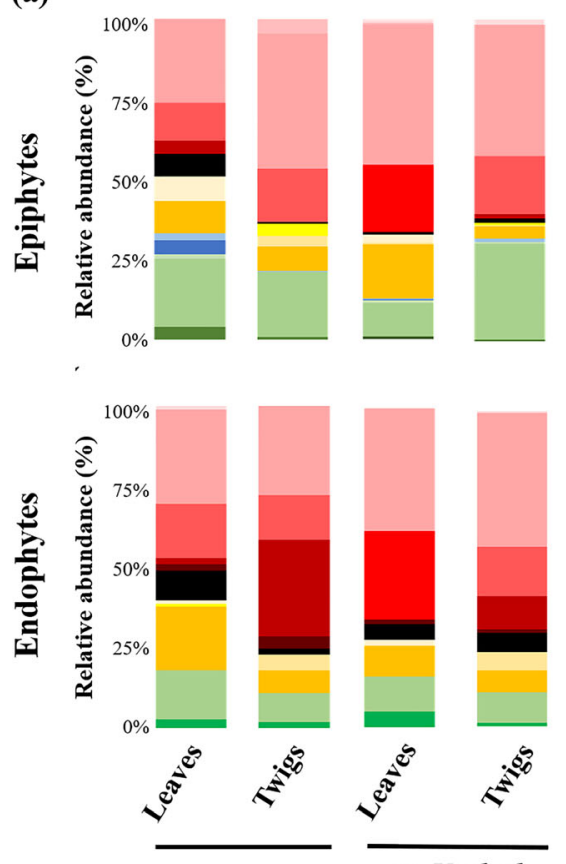

cv. Cobrançosa

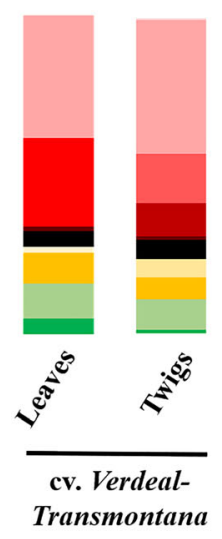

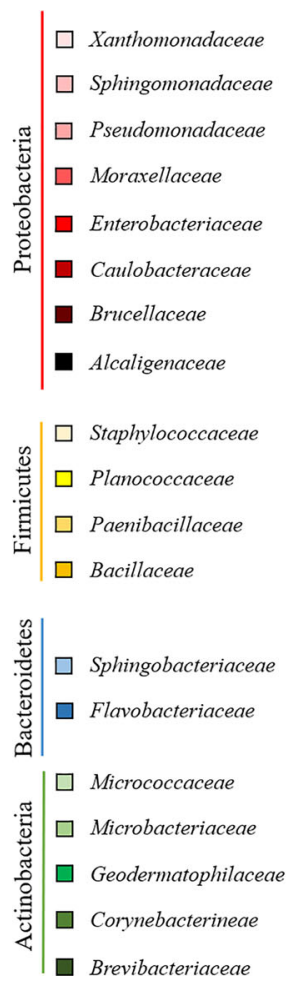

(b)
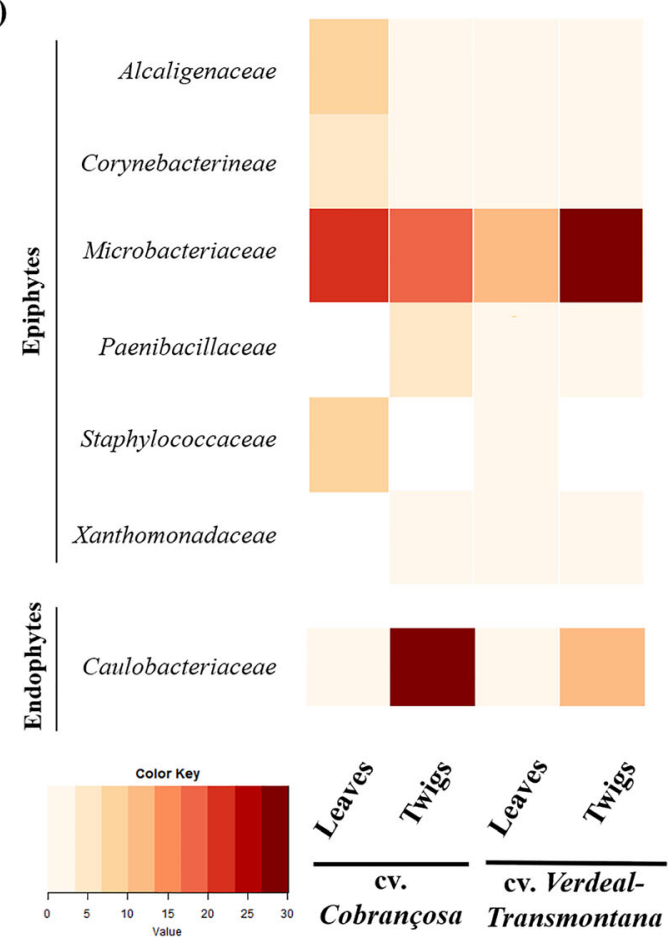

Fig. 4 Relative abundance of bacterial families (and respective phyla) of epiphytes and endophytes present in leaves and twigs of olive tree cv. Cobrançosa and cv. Verdeal-Transmontana. (a) Relative abundance of bacterial families; (b) Relative abundance of bacterial families that

reported to protect the host plant from drought and high temperature [53], which are considered serious abiotic stresses of crop plants in the Mediterranean region.

In this work, the olive plant habitat (internal vs. external plant tissues) revealed to be determinant for the bacterial community structure, as described previously for other plant species, such as Quercus ilex [54], and other non-perennial or Mediterranean species [8, 14]. Differences on nutrients and/ or environmental conditions between internal and external olive tree tissues could have influenced the selection of specific bacterial OTUs, giving rise to different bacterial communities within epiphytes and endophytes. In particular, a greater abundance of Actinobacteria and the exclusive presence of Bacteroidetes were observed within epiphytes as compared with endophytes colonizing the olive tree phyllosphere. This effect has been previously observed in the phyllosphere of several plant species $[55,56]$. The greater exposition to environmental conditions on the surface of olive leaves/twigs, as compared with internal plant tissues, could explain the dominance of bacterial members belonging to resistant phyla to desiccation and radiation within the epiphytic communities. As the Mediterranean regions are expected to be heavily impacted by climate change [57], the elucidation of bacterial taxa function in internal and external tissues of olive tree phyllosphere would be important to delineate future lines of action. exhibited significant $(p<0.05)$ differential abundance across host cultivar and plant organ. In $\mathbf{b}$, displayed differences were only detected on epiphytic or on endophytic environment, not on both

The diversity and composition of the entire bacterial community inhabiting the olive tree phyllosphere was significantly different between host genotypes (at cultivar level), suggesting a degree of host control over bacterial communities. Since the surveyed olive cultivars are growing close to one another and with the same management practices, the differences found on bacterial diversity and composition among cultivars are most probably related to differences on chemical/physical properties of both surveyed cultivars. Indeed, leaves of cvs. Cobrançosa and Verdeal Transmontana have already revealed differences on several physical and chemical parameters [58-60], and such features have long been considered to influence phyllospheric bacterial colonization [2, 61-63]. Thus, each olive tree cultivar apparently displays specific traits that govern phyllosphereassociated microbial assembly, as verified on olive fungal community by Gomes et al. [64]. This is consistent with other studies performed on bacterial communities associated to the phyllosphere of coffee [65] and cotton [66]. Additionally, our results suggest that host plant probably has more control over colonization of internal than of external tissues. Specific plant genotype traits, such as defense compounds production, have already been showed to act as habitat filters by influencing the establishment of microbial species within plant tissue [67]. The slightly low influence of host cultivar on epiphytic community composition may be related to the higher susceptibility of epiphytes to environmental factors when compared with 

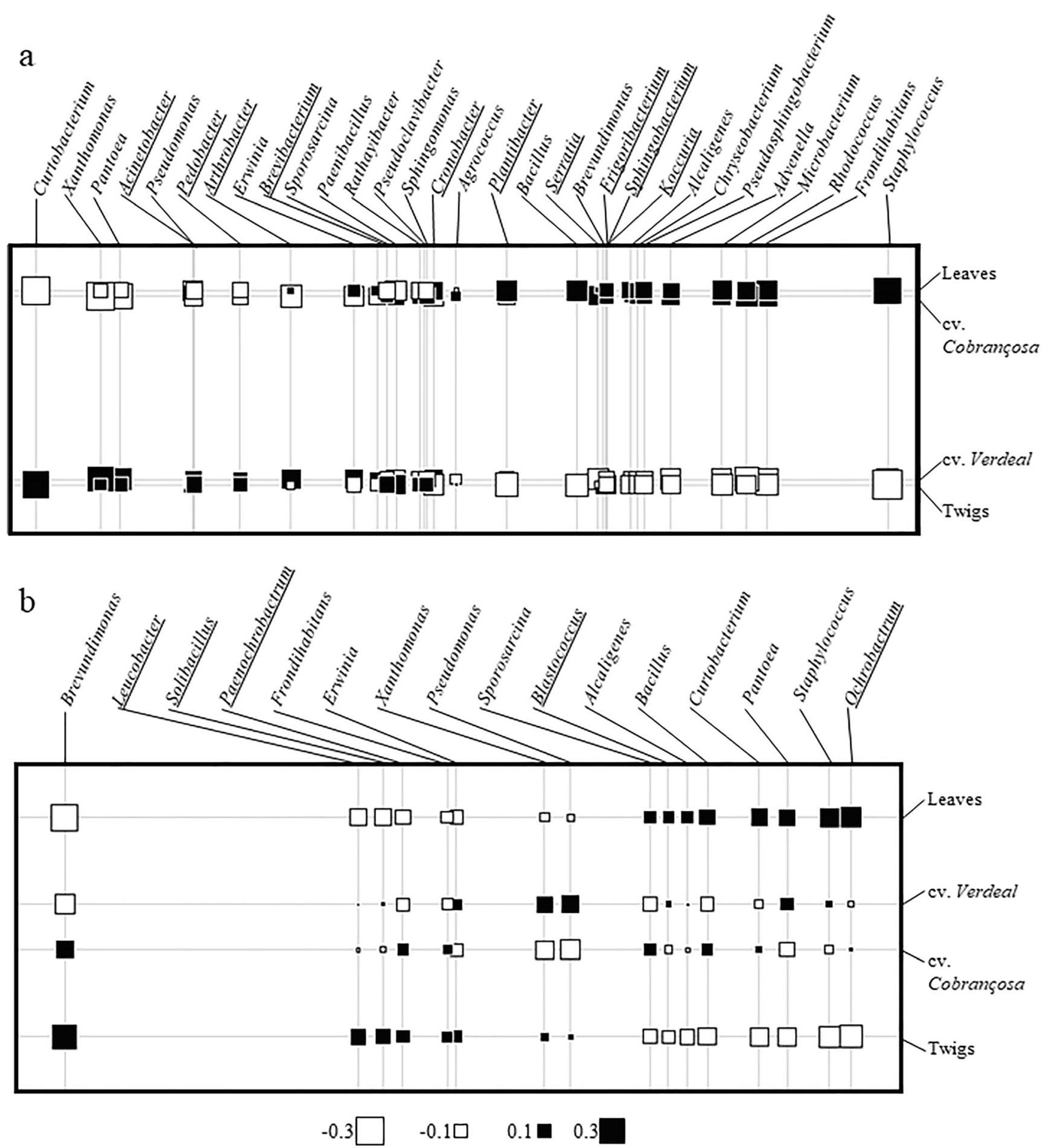

Fig. 5 Co-inertia factorial map of (a) epiphytic and (b) endophytic olive tree bacterial communities, presenting positive (filled square) and negative (open square) relationships with cultivars (Cobrançosa vs. Verdeal-Transmontana) and plant organs (leaves vs. twigs). The square

endophytes, as previously observed for fungal community inhabiting the olive tree phyllosphere [26].

The plant organ (leaves vs. twigs) was found to significantly affect the composition of bacterial communities in the olive tree phyllosphere, as reported in previous studies for other size indicates the degree of relatedness between variables (host cultivar or plant organ) and bacterial community. Underlined genera are exclusive from each community

plant species, like Coffea arabica [65], Pinus flexilis [9] or Populus [68]. This effect was greater within the epiphytic than within the endophytic bacterial communities, which could be related with the greater differences between leaves and twigs on their surfaces, when compared with the internal plant 
tissues. Indeed, the surface of both olive organs differ greatly on morphological traits and microenvironmental conditions [69], which were already known to influence the bacterial colonization of phyllosphere [63]. In comparison with twigs, olive leaves are exposed to more radiation and subjected to more desiccation, which are detrimental factors for bacterial colonization of leaf surfaces [7]. The higher abundance of bacterial epiphytes observed in twigs than in leaves support our hypothesis. In contrast, the reduced effect of plant organ on endophytic assemblage is probably due to the similarities of endospheric environment among leaves and twigs.

The bacterial specificity in each olive tree organ was found to be dependent on host cultivar. In cv. Verdeal Transmontana, bacterial epiphytes exhibited a higher degree of organ specificity than endophytes, while, in cv. Cobrançosa, the opposite was observed. This differential colonization patterns may be related to the variations on the physical (biometric measurements [59]) and chemical (flavonoid compounds, fatty acid profiles and plant volatiles [58-60]) features detected in both cultivars. Therefore, each host cultivar seems to have its own foliar/twig features, which would select for specific epiphytic/ endophytic bacterial communities. This hypothesis is corroborated by the high number of bacterial genera that were found to be positively associated with a specific cultivar/plant organ. Similarly, a high number of bacterial OTUs (at species level) that could be considered as specialists of one specific cultivar/ plant organ (i.e., that prefer one specific host cultivar) was found. Regarding the host cultivar, the number of bacterial OTUs characteristic of cv. Verdeal Transmontana was higher (26) than that of cv. Cobrançosa (16), suggesting a stronger effect of the former cultivar in selecting specific bacteria. The bacterial recruitment by plant has been mostly described for the rhizosphere [70, 71], while studies reporting phyllosphere selection are still lacking. From our findings, the bacterial recruitment occurring in the phyllosphere seems to be mainly affected by the host genotype, both for epiphytes or endophytes selection.

The phyllosphere of both cultivars seem to recruit a greater number of beneficial rather than pathogenic bacterial OTUs. This finding is in accordance with previous studies that showed a higher recruitment of beneficial microbes by the plant to obtain the maximum mutualistic benefits, not only under standard but also under stressful conditions [7, 71]. Indeed, most of the indicator bacteria of cv. Verdeal Transmontana comprise common plant beneficial members reported to have potential (i) to increase host resistance to climatic stresses (P. frederiksbergensis [72]), (ii) to improve plant growth (Curtobacterium herbarum [73]; P. lutea [74]) and (iii) to control a broad range of plant pathogens (Pantoea vagans [75, 76]; Bacillus cereus [77]; Pseudomonas orientalis [78]). Associated to this cultivar, several members of the fluorescent Pseudomonas genus (P. poae, P. baetica, P. congelans, P. fluorescens and P. mandelii) were also found, which have been reported to control several plant pathogens [79]. Cobrançosa cultivar had also several associated isolates described as potential antagonists of phytopathogens, such as Bacillus megaterium [80], Bacillus subtilis [81], Pantoea vagans [82] and Pseudomonas graminis [83]. Other isolates associated to Cobrançosa cultivar have been described to protect plants on stressful environments (Curtobacterium oceanosedimentum [84]). In contrast, microorganisms described as plant pathogens were detected on cv. Cobrançosa (Pseudomonas aeruginosa [85]). Future investigations should be conducted targeting on the ecological roles of these bacterial specialists in Mediterranean ecosystems.

In conclusion, in this work, the bacterial communities of olive tree phyllosphere revealed to be primarily impacted by host cultivar and, to a lesser extent, by plant organ. However, while host cultivar affects in a similar way the composition of endophytic and epiphytic bacterial community, the plant organ has greater influence on epiphytic than on endophytic bacterial community structure. Each olive cultivar/plant organ apparently was selective towards specific bacterial OTUs. The ecological roles of these bacteria need to be studied in the future because they might be important in supporting olive tree survival in Mediterranean regions. The host specificity demonstrated in this study also suggested that the benefits derived from the plant-bacteria interaction should be considered at genetic levels below the species.

Acknowledgments The authors are grateful to the FEDER and Foundation for Science and Technology (FCT, Portugal) under Programme PT2020 for financial support to CIMO (UID/AGR/00690/ 2019) and BioISI (UID/MULTI/04046/2013), as well as the Horizon 2020, the European Union's Framework Programme for Research and Innovation, for financial support the project PRIMA/0002/2018 INTOMED-Innovative tools to combat crop pests in the Mediterranean. D. Mina thanks FCT, POPH-QREN and FSE for SFRH-BD-105341/2014 grant.

\section{References}

1. Bringel F, Couée I (2015) Pivotal roles of phyllosphere microorganisms at the interface between plant functioning and atmospheric trace gas dynamics. Front Microbiol 6:486. https://doi.org/10.3389/ fmicb.2015.00486

2. Lindow SE, Brandl MT (2003) Microbiology of the phyllosphere. Appl Environ Microbiol 69:1875-1883. https://doi.org/10.1128/ AEM.69.4.1875-1883.2003

3. Leach JE, Triplett LR, Argueso CT, Trivedi P (2017) Communication in the phytobiome. Cell 169:587-596. https:// doi.org/10.1016/j.cell.2017.04.025

4. Newton AC, Gravouil C, Fountaine JM (2010) Managing the ecology of foliar pathogens: ecological tolerance in crops. Ann Appl Biol 157:343-359. https://doi.org/10.1111/j.1744-7348.2010. 00437.x

5. Bulgarelli D, Schlaeppi K, Spaepen S, van Themaat EVL, SchulzeLefert P (2013) Structure and functions of the bacterial microbiota 
of plants. Annu Rev Plant Biol 64:807-838. https://doi.org/10. 1146/annurev-arplant-050312-120106

6. O'Brien PA (2017) Biological control of plant diseases. Australas Plant Path 46:293-304. https://doi.org/10.1007/s13313-017-04814

7. Vorholt JA (2012) Microbial life in the phyllosphere. Nat Rev Microbiol 10:828-840. https://doi.org/10.1038/nrmicro2910

8. Bodenhausen N, Horton MW, Bergelson J (2013) Bacterial communities associated with the leaves and the roots of Arabidopsis thaliana. PLoS One 8:e56329. https://doi.org/10.1371/journal.pone.0056329

9. Carper DL, Carrell AA, Kueppers LM, Frank AC (2018) Bacterial endophyte communities in Pinus flexilis are structured by host age, tissue type, and environmental factors. Plant Soil 428:335-352. https://doi.org/10.1007/s11104-018-3682-x

10. Kim M, Singh D, Lai-Hoe A, Go R, Abdul Rahim R, Ainuddin AN, Chun J, Adams JM (2012) Distinctive phyllosphere bacterial communities in tropical trees. Microb Ecol 63:674-681. https://doi.org/ 10.1007/s00248-011-9953-1

11. Lambais MR, Lucheta AR, Crowley DE (2014) Bacterial community assemblages associated with the phyllosphere, dermosphere, and rhizosphere of tree species of the Atlantic forest are host taxon dependent. Microb Ecol 68:567-574. https://doi.org/10.1007/ s00248-014-0433-2

12. Laforest-Lapointe I, Messier C, Kembel SW (2016) Tree phyllosphere bacterial communities: exploring the magnitude of intra- and inter-individual variation among host species. PeerJ 4: e2367. https://doi.org/10.7717/peerj.2367

13. Redford AJ, Bowers RM, Knight R, Linhart Y, Fierer N (2010) The ecology of the phyllosphere: geographic and phylogenetic variability in the distribution of bacteria on tree leaves. Environ Microbiol 12:2885-2889. https://doi.org/10.1111/j.1462-2920.2010.02258.x

14. Hunter PJ, Hand P, Pink D, Whipps JM, Bending GD (2010) Both leaf properties and microbe-microbe interactions influence withinspecies variation in bacterial population diversity and structure in the lettuce (Lactuca species) phyllosphere. Appl Environ Microbiol 76:8117-8125. https://doi.org/10.1128/AEM.01321-10

15. Rastogi G, Sbodio A, Tech JJ, Suslow TV, Coaker GL, Leveau JHJ (2012) Leaf microbiota in an agroecosystem: spatiotemporal variation in bacterial community composition on field-grown lettuce. ISME J 6:1812-1822. https://doi.org/10.1038/ismej.2012.32

16. Khare E, Mishra J, Arora NK (2018) Multifaceted interactions between endophytes and plant: developments and prospects. Front Microbiol 9:2732. https://doi.org/10.3389/fmicb.2018.02732

17. Loumou A, Giourga C (2003) Olive groves: the life and identity of the Mediterranean. Agric Hum Values 20:87-95. https://doi.org/10. 1023/A:1022444005336

18. Barranco D, Fernández-Escobar R, Rallo L (2008) El Cultivo del olivo. Junta de Andalucía y Ediciones8th edn. Mundi-Prensa, Madrid

19. Belda M, Holtanová E, Halenka T, Kalvová J (2014) Climate classification revisited: from Köppen to Trewartha. Clim Res 59:1-13. https://doi.org/10.3354/cr01204

20. Lopez-Llorca LV, Macia-Vicente JG (2009) Plant symbioses with fungal endophytes: perspectives on conservation and sustainable exploitation of Mediterranean ecosystems. Mediterranea 20:1047. https://doi.org/10.14198/MDTRRA2009.20.03

21. Gualdi $\mathrm{S}$ et al (2013) Future climate projections. In: Navarra A, Tubiana L (eds) Regional assessment of climate change in the Mediterranean, Advances in Global Change Research 50. Springer, pp 53-118. https://doi.org/10.1007/978-94-007-5781-3_3

22. Fisher PJ, Petrini O, Petrini LE, Descals E (1992) A preliminary study of fungi inhabiting xylem and whole stems of Olea europaea. Sydowia 44:117-121

23. Sia EF, Marcon J, Luvizotto DM, Quecine MC, Tsui S, Pereira JO, Pizzirani-Kleiner AA, Azevedo JL (2013) Endophytic fungi from the Amazonian plant Paullinia cupana and from Olea europaea isolated using cassava as an alternative starch media source. SpringerPlus 2:579. https://doi.org/10.1186/2193-1801-2-579

24. Torres M, Dolcet MM, Sala N, Canela R (2013) Endophytic fungi associated with Mediterranean plants as a source of myceliumbound lipases. J Agric Food Chem 51:3328-3333. https://doi.org/ $10.1021 / \mathrm{jf0} 25786 \mathrm{u}$

25. Martins F, Pereira JA, Bota P, Bento A, Baptista P (2016) Fungal endophyte communities in above- and belowground olive tree organs and the effect of season and geographic location on their structures. Fungal Ecol 20:193-201. https://doi.org/10.1016/j.funeco.2016.01.005

26. Gomes T, Pereira JA, Benhadi J, Lino-Neto T, Baptista P (2018) Endophytic and epiphytic phyllosphere fungal communities are shaped by different environmental factors in a Mediterranean ecosystem. Microb Ecol 76:668-679. https://doi.org/10.1007/s00248-018-1161-9

27. Müller H, Berg C, Landa BB, Auerbach A, Moissl-Eichinger C, Berg F (2015) Plant genotype-specific archaeal and bacterial endophytes but similar Bacillus antagonists colonize Mediterranean olive trees. Front Microbiol 6(138). https://doi.org/10.3389/fmicb. 2015.00138

28. Malavolta C, Perdikis D (2012) Guidelines for integrated production of olives. IOBC technical guideline III, 2nd edition, 19pp

29. Cai L, Ye L, Tong AHY, Lok S, Zhang T (2013) Biased diversity metrics revealed by bacterial 16S pyrotags derived from different primer sets. PLoS One 8:e53649. https://doi.org/10.1371/journal. pone.0053649

30. Yarza P, Yilmaz P, Pruesse E, Glöckner FO, Ludwig W, Schleifer K, Whitman WB, Euzéby J, Amann R, Rosselló-Móra R (2014) Uniting the classification of cultured and uncultured bacteria and archaea using 16S rRNA gene sequences. Nat Rev Microbiol 12: 635-645. https://doi.org/10.1038/nrmicro3330

31. Seaby RM, Henderson PA (2006) Species diversity and richness version 4. Pisces Conservation Ltd., Lymington

32. Magurran AE (2013) Measuring biological diversity. WileyBlackwell, $264 \mathrm{pp}$,

33. Clarke KR (1993) Non-parametric multivariate analysis of changes in community structure. Aust J Ecol 18:117-143. https://doi.org/10. 1111/j.1442-9993.1993.tb00438.x

34. Clarke KR, Gorley RN (2006) PRIMER v6: user manual/tutorial (plymouth routines in multivariate ecological research). PRIMERE, Plymouth

35. Henderson PA, Seaby RMH (2007) Community analysis package 4.0 Pisces. Conservation ltd, Lymington

36. R Core Team (2018) R: A language and environment for statistical computing. R Foundation for Statistical Computing, Vienna, Austria. URL: https://www.R-project.org/

37. Dufrêne M, Legendre P (1997) Species assemblages and indicator species: the need for a flexible asymmetrical approach. Ecol Monogr 67:345-366. https://doi.org/10.2307/2963459

38. Dolédec S, Chessel D (1994) Co-inertia analysis: an alternative method for studying species environment relationships. Freshw Biol 31:277294. https://doi.org/10.1111/j.1365-2427.1994.tb01741.x

39. Dray S, Dufour A (2007) The ade4 package: implementing the duality diagram for ecologists. J Stat Softw 22:1-20. https://doi. org/10.18637/jss.v022.i04

40. Josse J, Pagès J, Husson F (2008) Testing the significance of the RV coefficient. Comput Stat Data An 53:82-91. https://doi.org/10. 1016/j.csda.2008.06.012

41. Connor DJ (2005) Adaptation of olive (Olea europaea L.) to waterlimited environments. Aust J Agric Res 56:1181-1189. https://doi. org/10.1071/AR05169

42. Hug LA (2018) Sizing up the uncultured microbial majority. mSystems 3:e00185-e00118

43. Valverde A, González-Tirante M, Medina-Sierra M, Rivas R, Santa-Regina I, Igual JM (2017) Culturable bacterial diversity from the chestnut (Castanea sativa mill.) phyllosphere and antagonism against the fungi causing the chestnut blight and ink diseases. 
AIMS Microbiol 3:293-314. https://doi.org/10.3934/microbiol. 2017.2.293

44. Vokou D, Vareli K, Zarali E, Karamanoli K, Constantinidou HA, Monokrousos N, Halley JM, Sainis I (2012) Exploring biodiversity in the bacterial community of the Mediterranean phyllosphere and its relationship with airborne bacteria. Microb Ecol 64:714-724. https://doi.org/10.1007/s00248-012-0053-7

45. Makhalanyane TP, Valverde A, Gunnigle E, Frossard A, Ramond JB, Cowan DA (2015) Microbial ecology of hot desert edaphic systems. FEMS Microbiol Rev 39:203-221. https://doi.org/10. 1093/femsre/fuu011

46. Coleman-Derr D, Desgarennes D, Fonseca-Garcia C, Gross S, Clingenpeel S, Woyke T, North G, Visel A, Partida-Martinez LP, Tringe SG (2016) Plant compartment and biogeography affect microbiome composition in cultivated and native Agave species. New Phytol 209:798-811. https://doi.org/10.1111/nph.13697

47. Sun Y, Shi YL, Wang H, Zhang T, Yu LY, Sun H, Zhang YQ (2018) Diversity of bacteria and the characteristics of actinobacteria community structure in Badain Jaran desert and Tengger desert of China. Front Microbiol 9:1068. https://doi.org/10.3389/fmicb.2018.01068

48. Vikram S, Guerrero LD, Makhalanyane TP, Le PT, Seely M, Cowan DA (2016) Metagenomic analysis provides insights into functional capacity in a hyperarid desert soil niche community. Environ Microbiol 18:1875-1888

49. Stankovic N, Radulovic V, Petkovic M, Vuckovic I, Jadranin M, Vasiljevic B, Nikodinovic-Runic J (2012) Streptomyces sp. JS520 produces exceptionally high quantities of undecylprodigiosin with antibacterial, antioxidative, and UV-protective properties. Appl Microbiol Biotechnol 96:1217-1231. https://doi.org/10.1007/ s00253-012-4237-3

50. Makarova KS, Aravind L, Wolf YI, Tatusov RL, Minton KW, Koonin EV, Daly MJ (2001) Genome of the extremely radiationresistant bacterium Deinococcus radiodurans viewed from the perspective of comparative genomics. Microbiol Mol Biol Rev 65:44 79. https://doi.org/10.1128/MMBR.65.1.44-79.2001

51. Swick MC, Koehler TM, Driks A (2016) Surviving between hosts: sporulation and transmission. Microbiol Spectr 4(4):VMBF00292015. https://doi.org/10.1128/microbiolspec.VMBF-0029-2015

52. Hussain SS, Mehnaz S, Siddique KHM (2018) Harnessing the plant microbiome for improved abiotic stress tolerance. In: Egamberdieva D, Ahmad P (eds) Plant microbiome: stress response. Springer Nature Singapore Pte Ltd., pp 21-43. https://doi. org/10.1007/978-981-10-5514-0_2

53. Peñuelas J, Rico L, Ogaya R, Jump S, Terradas J (2012) Summer season and long-term drought increase the richness of bacteria and fungi in the foliar phyllosphere of Quercus ilex in a mixed Mediterranean forest. Plant Biol 14:565-575. https://doi.org/10. 1111/j.1438-8677.2011.00532.x

54. Agler MT, Ruhe J, Kroll S, Morhenn C, Kim ST, Weigel D, Kemen EM (2016) Microbial hub taxa link host and abiotic factors to plant microbiome variation. PLoS Biol 14:e1002352. https://doi.org/10. 1371/journal.pbio.1002352

55. Wagner MR, Lundberg DS, del Rio TG, Tringe SG, Dangl JL, Mitchell-Olds T (2016) Host genotype and age shape the leaf and root microbiomes of a wild perennial plant. Nat Commun 7:12151. https://doi.org/10.1038/ncomms 12151

56. Cramer W, Guiot J, Fader M, Garrabou J, Gattuso J-P, Iglesias A, Lange MA, Lionello P, Llasat MC, Paz S, Peñuelas J, Snoussi M, Toreti A, Tsimplis MN, Xoplaki E (2018) Climate change and interconnected risks to sustainable development in the Mediterranean. Nat Clim Chang 8:972-980. https://doi.org/10.1038/s41558-018-0299-2

57. Meirinhos J, Silva BM, Valentão P, Seabra RM, Pereira JA, Dias A, Andrade PB, Ferreres F (2005) Analysis and quantification of flavonoidic compounds from Portuguese olive (Olea europaea L.) leaf cultivars. Nat Prod Res 19:189-195. https://doi.org/10.1080/ 14786410410001704886
58. Malheiro R, Casal S, Baptista P, Pereira JA (2015) Physicochemical characteristics of olive leaves and fruits and their relation with Bactrocera oleae (Rossi) cultivar oviposition preference. Sci Hortic 194:208-214. https://doi.org/10.1016/j.scienta.2015.08.017

59. Malheiro R, Casal S, Cunha SC, Baptista P, Pereira JA (2016) Identification of leaf volatiles from olive (Olea europaea) and their possible role in the ovipositional preferences of olive fly, Bactrocera oleae (Rossi) (Diptera: Tephritidae). Phytochem 121: 11-19. https://doi.org/10.1016/j.phytochem.2015.10.005

60. Yadav RKP, Karamanoli K, Vokou D (2005) Bacterial colonization of the phyllosphere of Mediterranean perennial species as influenced by leaf structural and chemical features. Microb Ecol 50: 185-196. https://doi.org/10.1007/s00248-004-0171-y

61. Ruppel S, Krumbein A, Schreiner M (2008) Composition of the phyllospheric microbial populations on vegetable plants with different glucosinolate and carotenoid compositions. Microb Ecol 56: 364-372. https://doi.org/10.1007/s00248-007-9354-7

62. Lemanceau P, Barret M, Mazurier S, Mondy S, Pivato B, Fort T, Vacher C (2017) Plant communication with associated microbiota in the spermosphere, rhizosphere and phyllosphere. Adv Bot Res 82:101-133. https://doi.org/10.1016/bs.abr.2016.10.007

63. Gomes T, Pereira JA, Lino-Neto T, Bennett AE, Baptista P (2019) Bacterial disease induced changes in fungal communities of olive tree twigs depend on host genotype. Sci Rep 9:5882. https://doi.org/ 10.1038/s41598-019-42391-8

64. Vega F, Pava-Ripoll M, Posada F, Buyer J (2005) Endophytic bacteria in Coffea arabica L. J Basic Microbiol 45:371-380. https:// doi.org/10.1002/jobm.200410551

65. Adams PD, Kloepper JW (2002) Effect of host genotype on indigenous bacterial endophytes of cotton (Gossypium hirsutum L). Plant Soil 240:181-189. https://doi.org/10.1023/A: 1015840224564

66. Saunders M, Glenn AE, Kohn LM (2010) Exploring the evolutionary ecology of fungal endophytes in agricultural systems: using functional traits to reveal mechanisms

67. Cregger MA, Veach AM, Yang ZK, Crouch MJ, Vilgalys R, Tuskan GA, Schadt CW (2018) The Populus holobiont: dissecting the effects of plant niches and genotype on the microbiome. Microbiome 6:31. https://doi.org/10.1186/s40168-018-0413-8

68. Fernández J (2014) Understanding olive adaptation to abiotic stresses as a tool to increase crop performance. Environ Exp Bot 103:158-179. https://doi.org/10.1016/j.envexpbot.2013.12.003

69. Patel JS, Singh A, Singh HB, Sarma BK (2015) Plant genotype, microbial recruitment and nutritional security. Front Plant Sci 6: 608. https://doi.org/10.3389/fpls.2015.00608

70. Tena G (2018) Recruiting microbial bodyguards. Nat Plants 4:857857. https://doi.org/10.1038/s41477-018-0308-5

71. Ortega RA, Mahnert A, Berg C, Müller H, Berg G (2016) The plant is crucial: specific composition and function of the phyllosphere microbiome of indoor ornamentals. FEMS Microbiol Ecol 92(12): fiw173. https://doi.org/10.1093/femsec/fiw173

72. Subramanian P, Kim K, Krishnamoorthy R, Mageswari A, Selvakumar G, Sa T (2016) Cold stress tolerance in psychrotolerant soil bacteria and their conferred chilling resistance in tomato (Solanum lycopersicum mill.) under low temperatures. PLoS One 11(8):e0161592. https://doi.org/10.1371/journal.pone.0161592

73. Díez-Méndez A, Rivas R (2017) Improvement of saffron production using Curtobacterium herbarum as a bioinoculant under greenhouse conditions. AIMS Microbiol 3:354-364. https://doi.org/10. 3934/microbiol.2017.3.354

74. Peix A, Rivas R, Santa-Regina I, Mateos PF, Martínez-Molina E, Rodríguez-Barrueco C, Velázquez E (2004) Pseudomonas lutea sp. nov., a novel phosphate-solubilizing bacterium isolated from the rhizosphere of grasses. Int J Syst Evol Microbiol 54:847-850. https://doi.org/10.1099/ijs.0.02966-0 
75. Pusey PL (2002) Biological control agents for fire blight of apple compared under conditions limiting natural dispersal. Plant Dis 86: 639-644. https://doi.org/10.1094/PDIS.2002.86.6.639

76. Walterson AM, Stavrinides J (2015) Pantoea: insights into a highly versatile and diverse genus within the Enterobacteriaceae. FEMS Microbiol Rev 39:968-984. https://doi.org/10.1093/femsre/fuv027

77. Shafi J, Tian H, Ji M (2016) Bacillus species as versatile weapons for plant pathogens: a review. Biotechnol Biotechnol Equip 31: 446-459. https://doi.org/10.1080/13102818.2017.1286950

78. Zengerer V, Schmid M, Bieri M, Müller DC, Remus-Emsermann MNP, Ahrens CH, Pelludat C (2018) Pseudomonas orientalis F9: a potent antagonist against phytopathogens with phytotoxic effect in the apple flower. Front Microbiol 9:145. https://doi.org/10.3389/ fmicb.2018.00145

79. Müller T, Behrendt U, Ruppel S, von der Waydbrink G, Müller ME (2016) Fluorescent pseudomonads in the phyllosphere of wheat: potential antagonists against fungal phytopathogens. Curr Microbiol 72:383389. https://doi.org/10.1007/s00284-015-0966-8

80. Mohamed R, Groulx E, Defilippi S, Erak T, Tambong JT, Tweddell RJ, Tsopmo A, Avis TJ (2017) Physiological and molecular characterization of compost bacteria antagonistic to soil-borne plant pathogens. Can J Microbiol 63:411-426. https://doi.org/10.1139/ cjm-2016-0599
81. Torres MJ, Brandan CP, Petroselli G, Erra-Balsells R, Audisio MC (2016) Antagonistic effects of Bacillus subtilis subsp. subtilis and B. amyloliquefaciens against Macrophomina phaseolina: SEM study of fungal changes and UV-MALDI-TOF MS analysis of their bioactive compounds. Microbiol Res 182:31-39. https://doi.org/10. 1016/j.micres.2015.09.005

82. Sharifazizi M, Harighi B, Sadeghi A (2017) Evaluation of biological control of Erwinia amylovora, causal agent of fire blight disease of pear by antagonistic bacteria. Biol Control 104:28-34. https://doi.org/10.1016/j.biocontrol.2016.10.007

83. Mikiciński A, Sobiczewski P, Puławska J, Malusa E (2016) Antagonistic potential of Pseudomonas graminis 49M against Erwinia amylovora, the causal agent of fire blight. Arch Microbiol 198:531-539. https://doi.org/10.1007/s00203-016-1207-7

84. Khan MA, Asaf S, Khan AL, Ullah I, Ali S, Kang S, Lee I (2019) Alleviation of salt stress response in soybean plants with the endophytic bacterial isolate Curtobacterium sp. SAK1. Ann Microbiol 1:12-808. https://doi.org/10.1007/s13213-019-01470-x

85. Bose D, Chatterjee S (2016) Biogenic synthesis of silver nanoparticles using guava (Psidium guajava) leaf extract and its antibacterial activity against Pseudomonas aeruginosa. Appl Nanosci 6: 895-901. https://doi.org/10.1007/s13204-015-0496-5 